\title{
The New Frontier for Labor in Trade Agreements
}

\author{
Alvaro Santos \\ Georgetown University Law Center, asantos@law.georgetown.edu
}

This paper can be downloaded free of charge from:

https://scholarship.law.georgetown.edu/facpub/2233

https://ssrn.com/abstract=3538477

Alvaro Santos, The New Frontier for Labor in Trade Agreements, in World Trade and Investment Law Reimagined: A Progressive Agenda for an Inclusive Globalization 215-223 (Alvaro Santos, Chantal Thomas \& David Trubek eds., London: Anthem Press 2019).

This open-access article is brought to you by the Georgetown Law Library. Posted with permission of the author. Follow this and additional works at: https://scholarship.law.georgetown.edu/facpub

Part of the International Trade Law Commons, Labor and Employment Law Commons, and the Law and Economics Commons 


\title{
THE NEW FRONTIER FOR LABOR IN TRADE AGREEMENTS
}

\begin{abstract}
Alvaro Santos
In the spring of 2015, I took my students of international trade law to visit the World Trade Organization (WTO) in Geneva. It was a two-day trip, organized around lectures and discussions with staff from different divisions of the organization, the Advisory Centre of WTO Law and the permanent missions of two countries. None of my students had been there before, and even though I had taught international trade law for several years, it was also my first time visiting the headquarters of the organization. We were excited and curious. The building looked big and majestic. The back side opened to a spacious park overlooking Lake Geneva. It made for a pleasant tour on a cool, sunny morning. The WTO was celebrating its 20th anniversary, and there were banners hanging from the walls in the internal atrium marking the occasion, as well as announcements of events to come.
\end{abstract}

In our second session, we were led to a room with wooden panels and a colorful mural that spanned the four walls. It depicted industrial workers - strong men making a car, miners, shipbuilders, men using heavy equipment, but also women, seamstresses, teachers and a few children. In the center a bare-chested man between two goddess-like women was holding a torch. The mural struck me as an ode to work, to achievement and to emancipation. A tale of the human race transforming the world through physical and intellectual labor. The painting, by Dean Cornwell, reminded me of the frescos of Mexican artist Diego Rivera in its depiction of industrial workers, although this one had no reference to exploitation or the confrontation between capital and labor. It was an incredibly optimistic image of work and human progress.

I was surprised to see a mural of workers in the WTO. The painting seemed not only vintage but also out of place. What was it doing here? We learned that the mural had been hidden for years and it was only in 2007 that it was discovered and unveiled. It turned out that the building had been the headquarters of the International Labor Organization (ILO), and when the ILO moved to another building in Geneva in 1975, the General Agreement on Tariffs and Trade (GATT) moved in. When the WTO was created in 1995, it took its place. In a different hall, we saw another painting with a construction worker front and center, surrounded by the text of the preamble of the Treaty of Versailles establishing the ILO. Below, a plaque memorialized its donation by the International Federation of Trade Unions. I had the impression that I was visiting the ruins of a bygone era. And I imagined what a different world that was, when labor was prominent and had power and money. When workers' organizations sat at the table. When they were "in the room where it happened." It was a feeling like the one I had when visiting the ruins of a Mayan city and imagining it in all its splendor, no doubt with a similar dose of romanticizing. How could labor have fallen so hard that it surprises me that they could have been hosted in a building like this, that they could have inspired such a narrative of triumph, and that yet, today, it does not make sense? There was something ironic about these images of labor reappearing in the walls of the WTO, where the linkage of trade and labor had been both discussed and resisted.

There was also something humbling at seeing that countries had set up an international organization to address labor and the "social" question almost 100 years before. Coming out of the first world war, the winning countries set up the ILO because they believed that peace could "be established only if it is based upon social justice" and because "the failure of any nation to 
adopt humane conditions of labour is an obstacle in the way of other nations which desire to improve the conditions in their own countries." There was a clear sense of interdependence and the need for coordination and collective action so as not to undermine each other. They set out to improve conditions of people by regulating:

... hours of work, including the establishment of a maximum working day and week, the regulation of the labour supply, the prevention of unemployment, the provision of an adequate living wage, the protection of the worker against sickness, disease and injury arising out of his employment, the protection of children, young persons and women, provision for old age and injury, protection of the interests of workers when employed in countries other than their own, recognition of the principle of freedom of association... ${ }^{1}$

Many of these laws were seen as unthinkable or as unnecessary in the era of classical legal thought where private contract law regulated relations among individuals in the market. Labor laws were the product of a legal imagination that defied the dominant legal constructs and upset the established order. The twentieth century witnessed many countries adopting national labor regulations, often in fits and starts, following their own domestic struggles and political processes. At the time of our visit, the WTO was suffering from a sense of growing irrelevance amidst the hype for other megaregional agreements. The great powers were seeking for deals, and for shaping global trade rules elsewhere. Although the WTO's dispute settlement system was busy and in high demand, the WTO as a forum for multilateral action seemed stagnant. Now, the WTO seems under threat, with the United States bluntly enacting measures that challenge its rules and undermining the proper staffing of its Appellate Body. Labor, jobs, wages and conditions of work have reemerged with force in the opposition to trade. Can we reimagine the shape of legal institutions and agreements, such as the WTO and other trade agreements, to usher in a different kind of globalization geared toward improving the lot of workers and benefiting those who have been left behind? What would that architecture look like?

\section{Farewell to Globalization's Gold Standard}

The United Kingdom's decision to leave the EU and the United States' decision to withdraw from the Trans-Pacific Partnership (TPP) and initially threaten to leave the North American Free Trade Agreement (NAFTA) gave a serious blow to the hopes that opposition to globalization would dwindle once political campaigns gave way to governing. A string of nationalist, populist parties who are critical of globalization are gaining strength in Europe. Moreover, the Trump administration's recent imposition of tariffs on steel and aluminum, and then on China more generally, along with Chinese retaliation, has led many commentators to declare a "trade war" and warn about the potential unraveling of the world trading system. In the face of the Trump administration's actions, many commentators evoke, somewhat nostalgically, the WTO's accomplishments and rules-based multilateral character. Responses to the current crisis urge a defense of existing institutions and a return to the underpinning international commitments that ushered in the current global economy. The hope seems to be to contain the Trump administration in action, even if the combative and inflammatory rhetoric continues. These responses assume that all would be well if we could simply respect and enforce the existing agreements. I argue that the attempt to preserve liberal globalization as we knew it is wrongheaded. It ignores that the current retrenchment to nationalism and the opposition to

\footnotetext{
${ }^{1}$ Treaty of Versailles, Part XIII, http://www.ilo.org/public/libdoc/ilo/1920/20B09_18_engl.pdf.
} 
international trade is a reaction to the effects of liberal globalization. Preserving the existing architecture won't dissipate, and may even increase the discontent.

Consider the TPP. It is symbolically important because the Obama administration and TPP supporters advanced it as the "gold standard" of globalization. I would contend that just as in the twentieth century, when the United States abandoned the gold standard for global monetary policy, the "gold standard" for international trade agreements has, too, been abandoned. Recently, however, the remaining 11 members of the TPP, now called the Comprehensive and Progressive Agreement for Trans-Pacific Partnership (CPTPP) without the United States, have resurrected it and are charging ahead. Unfortunately, they are not seizing the moment for charting a new path. The challenge is precisely to resist the temptation to preserve the existing trade agreements as they are in the hopes that the nationalist turn can be contained. The task is to design an alternative to both liberal globalization as we know it and the nationalistic turn currently seen in various governments around the world.

\section{The Rise and Fall of Labor Chapters}

The standard response to concerns about labor has been to include a "labor chapter" in trade agreements. Starting with NAFTA, gradually evolving in a multitude of trade agreements and then reaching its apex in the TPP, labor standards have been strengthened substantially and procedurally. Whereas in NAFTA countries agreed to enforce their own domestic labor laws, the TPP incorporates internationally recognized labor standards contained in the ILO's Declaration of Fundamental Principles and Rights at Work. Similarly, whereas in NAFTA labor obligations were contained in a side agreement, in the TPP they are a constitutive part of the agreement, like any other area. Whereas sanctions in NAFTA were limited, the TPP contains a dispute settlement system that may lead to trade sanctions.

So, if the TPP contained the most advanced of the labor chapters ever, why did the labor organizations in the United States oppose it? They argued that the substantive obligations did not go far enough. The rights often were vague, aspirational, or their implementation was left to the discretion of the governments, rendering them ineffective. Moreover, the chapter did not improve on the procedural hurdles any claim needed to jump in order to succeed. It still requires the state to bring up the claim, unlike the investment chapter, where private parties have standing. Moreover, it preserved the requirements that labor violations be systematic and "in a manner affecting trade" to trigger action. In the only labor case ever decided in a trade agreement, eight years after the United States brought the case against Guatemala under Dominican Republic-Central America-United States Free Trade Agreement (CAFTA), the 2017 panel decision interpreted the term "in a manner affecting trade" as requiring that a labor standard violation conferred a competitive advantage on employers engaged in trade between the parties. This interpretation, in addition to the requirement that the violation be "sustained or recurring," imposed a very high threshold and made the panel decide that Guatemala had not breached its commitments. Labor unions understandably asked, unsuccessfully, that such requirement be removed from the labor chapter.

Proponents of the TPP, however, made so much of the labor chapter that it seemed more a mechanism for legitimating the agreement than anything else. If the parties to a trade agreement wanted to address concerns about jobs, wages and working conditions, how would they do that? How would they make these concerns structurally central to the design of the agreement rather 
than formally relevant with a chapter that talks about labor? The point here is that by pretending that the labor chapter addresses these questions, the design and liberalization ethos of trade agreements is left otherwise unchanged. I propose that we invert the assumption and instead conclude that labor chapters, as currently proposed, will not address the concerns of organized labor. What, then, would be the tools to address these concerns? To put it bluntly, if we were to eliminate the labor chapter, what instruments would there be in the trade agreements to improve working conditions and benefit workers?

\section{The New Frontier for Labor}

Our current legal and institutional imagination seems seriously constrained when the hopes to improve working conditions are pinned on an accommodation to labor with a special chapter in a trade agreement. The more useful question may be how to rebalance key levers for distribution of power and wealth at international and domestic levels to reach a different equilibrium. Reform may be directed both at international rules that shape the existing global market and at the domestic level, where the effects of those global rules are felt by market actors. At the international level, labor advocates may gain by focusing on legal regimes, such as investment, government procurement, tax and immigration. At the domestic level, labor groups may gain from focusing on labor-related initiatives, like minimum wage and collective bargaining. But they may have much to gain, too, by focusing on background policy regimes that greatly affect workers, such as safety nets traditionally associated with good, stable jobs like health insurance, maternity leave and child care; investment in human capital such as education and training; and compensatory mechanisms such as unemployment insurance, income support and job placement programs.

This list is more a map than an agenda. Any one of these, or a combination of several, may hold promise depending on the context. The current regulation of investment affords foreign investors a standard of protection unknown in any other trade domain where the baseline is national treatment. In this regime, foreign investors are given greater protection than national investors. Labor organizations in the United States worry that this treatment may be encouraging outsourcing, although the empirical evidence seems to cast doubt on a direct relationship between an investment treaty and foreign direct investment. Nevertheless, investment rules may considerably constrain the regulatory autonomy of host countries in areas of public interest such as health and safety, the environment and labor. Investor rights are defined too broadly and too generously, making the state liable for actions that would be perfectly fine under many countries' legal orders. Granting investors standing to sue states in transnational panels, thereby circumventing national courts, empowers investors vis-à-vis the state and gives corporate interests a privileged position in relation to the public interest.

Finally, scholars have pointed out the potential conflict of interest of ad hoc arbitrators, who often serve as litigators in other cases and who have an interest in being appointed to subsequent arbitral panels given reputational and financial rewards. Substantively, critics have proposed reducing the scope of investor protection. Procedurally, some have proposed establishing a permanent court, including an appellate body staffed by judges and other jurists not drawn from the investment arbitration circuit, which could review judgements, better balance corporate and public interests, and bring consistency to the regime. The Canada-EU investment chapter moves clearly in this direction, and initial proposals to eliminate NAFTA Chapter 11 went a step further. 
Labor organizations have sought to stop the further liberalization of or to scale back the government procurement rules in trade agreements. The objective would be twofold: first, to use public procurement as a mechanism for job creation domestically, via local content requirements, and second, to use government procurement as a deliberate tool for economic stimulus in times of economic downturn. This cuts against the trends of megaregional agreements, like the TPP, which bind governments to nondiscrimination rules in their procurement. However, government procurement exists only as a plurilateral agreement in the WTO binding only countries who have expressly agreed to join it. Of the current 164 WTO members, only 47 are members. This would be an important area for countries to experiment and exercise flexibility. It would not even have to translate into an absolute required preference for domestic goods but into an advantage, using certain benchmarks as discipline. Conversely, government procurement rules can be designed to impose requirements related to compliance with robust labor standards, subject to certification. Given that public investment in infrastructure seems to be one of the very few areas where liberal and conservatives agree on the need of an active role of the state, this may even be a plausible area to carve out from future trade agreements.

Other scholars have proposed a new anti-social-dumping remedy, modeled after the existing antidumping remedies, where countries may impose tariffs on products made in violation of labor standards. The idea here would be to protect a domestically established social norm (respect for fundamental labor rights) in the market of the importing country from erosion due to competition with nonconforming states. Thus, importing countries would deem those imports as social dumping and, given their unfair character, subject to remedies. In designing such a legal remedy, proponents would need to elaborate details as to what standards would count as the baseline. For example, would it be their own? Internationally recognized labor standards? The bare minimum such as prohibition on forced labor, discrimination and child labor, and freedom of association and collective bargaining? Or more "robust" standards such as a living wage? Would the violations need to constitute a systematic "pattern"? Would there be a comparison with effectiveness of labor standards in the importing country? How would injury to the domestic industry of like products be determined? And what would the requirement for a causal link be? These are criteria that would need to be spelled out, but the principle is appealing because it would bring the labor conditions under which products are made to the center of the trade regime.

The existing space in the WTO should be used and expanded for the imposition of tariffs on goods produced under conditions that violate basic labor standards. Using existing mechanisms in the WTO would include distinguishing products on the basis of how they were made, under the GATT III national treatment obligation, invoking the public morals exception under GATT $\mathrm{XX}$ (a), as well as exploring the use of technical regulations, such as labeling under the Agreement on Technical Barriers to Trade (TBT Agreement). These avenues would need to be explored by a country willing to enact a measure, but the time seems ripe.

Finally, we can draw a lesson from the TPP negotiation that has gone largely overlooked. This consists in the significant domestic labor law reforms set in motion by Vietnam, formally agreed in a US-Vietnam Labor Consistency Plan, and by Mexico, informally, via US pressure. Vietnam agreed to end the monopoly of the government-controlled official union by allowing the formation of independent unions, enabling them to collect membership dues and allowing technical assistance and training by international workers organizations, among many other 
changes. Mexico passed a constitutional reform that would dismantle entrenched vices of its corporatist system, which had been demanded for years by independent unions and civil society but resisted by the government, employers and official unions. The reform sought to change the dispute settlement system, eliminating the tripartite Arbitration and Conciliation Board controlled by the Executive and giving jurisdiction over labor matters to the courts. Similarly, it would transfer the authority to register unions and collective agreements away from the Ministry of Labor and into a new autonomous institute, which would also guarantee free and secrete elections in disputes between unions. These reforms were scaled back (Vietnam) or derailed (Mexico) once the United States withdrew and the original TPP failed. It seems that the period during the negotiation of international trade agreements and before they enter into force provides the greatest leverage for influencing domestic reforms, considerably more than the operation of any labor chapter or future state vs. state litigation based on labor rights. This was confirmed in the negotiations over NAFTA (see "Epilogue" below).

This moment is ripe for rethinking. The legal and political architecture that shaped liberal globalization in the last three decades - the WTO, EU, NAFTA, myriad preferential trade agreements and bilateral investment treaties - has come under attack in the industrialized world. We should resist the temptation to defend these institutions wholesale, as if they represented the last line of defense against the ugly side of nationalism, populism and unilateralism in favor of prosperity and freedom. This opening to reshape the global institutions is an opportunity to remake the global markets and their effects, to change the equilibrium between capital and labor, to make globalization more attuned to domestic political processes and to make it work for those who have been left behind. To be sure, we cannot go back to the utopia of the industrial workers depicted in the WTO mural - a lost paradise that perhaps never was. The nature of work, production and organization has changed dramatically since then. But we can attempt to rediscover work, in all its forms, as central to our global market institutions.

\section{Epilogue}

After completion of this essay and beginning in July 2018, I had the privilege to serve as the deputy chief negotiator for the elected government of Mexico in the last stage of the NAFTA negotiation. The requisite reminder applies: the views expressed here are solely my own, and I make them as an academic long interested in the relationship between trade and labor. The United States-Mexico-Canada Agreement (USMCA), as it is now known in English, contains important changes beyond the labor chapter, anticipated by the American labor movement's critiques of the TPP.

The USMCA contains changes to the rules of origin, which increased the regional value content for a product to be considered North American and thus able to enjoy the Agreement's duty-free tariff. The most important of these changes took place in the auto sector, which increased the regional value content from 62.5 percent to 75 percent for passenger vehicles. In addition, 7 central parts that should originate in the region (meeting a minimum percentage threshold) for the vehicle to be considered originating, and the Agreement requires specific regional value percentages for other principal and complementary parts. Moreover, 70 percent of steel and aluminum used in autos should be regional in origin. For the first time in a trade agreement, 40 percent of labor value content must be produced with wages of $\$ 16$ per hour. The new rules are ostensibly designed to increase production in North America - and away from other regions like 
Asia. The rules were announced by the Trump administration as a way to incentivize auto companies to invest and stay in the United States, favoring US workers.

The new rules will require adjustments by the auto industry in the region and would be particularly challenging for Mexico. Its effects for Mexican automakers and workers will depend on how the industry, in combination with government policies, adjusts. Mexico could become an attractive investment destination for foreign companies interested in selling in the now more restricted US market. But the Mexican government working with the auto industry, can also try to expand the product range originating in Mexico and promote engineering, design and development in order to add greater value.

The labor chapter contains some changes when compared to the TPP. For a labor violation to be actionable, the text still requires that the violation be systematic and in a manner affecting trade. However, this latter clause is deliberately interpreted more loosely, to avoid a stringent interpretation that would require that the violation be shown to create a competitive disadvantage, as was required by the US-Guatemala panel. A violation would be considered to be "in a manner affecting trade" if it involves an export product or a domestic product that competes with imports. The chapter also contains a new provision on labor rights for migrant workers and an obligation to prevent violence against workers for exercising their rights.

Undoubtedly, the most important contribution to labor rights in the USMCA is the Labor Annex, in which Mexico commits itself to passing legislation ensuring freedom of association and collective bargaining. This legislation will implement the constitutional reform passed during the TPP negotiations. The reform stipulates the creation of an independent institute in charge of registering unions and collective bargaining agreements, as well as giving courts jurisdiction to solve labor disputes, thus ending the tripartite labor conciliation and arbitration boards, which have been a mainstay of Mexican corporatism and government control. A key part of the reform is the requirement of free, personal, direct and secret elections in the selection of union leadership and support for collective bargaining agreements. These changes have long been demanded by independent unions and proposed by progressive parties in Mexico. The Labor Annex's commitments now coincide with the new government's agenda, but, international commitments as they are, they lock in these obligations for the future independent of the agenda of the government in power.

Critics of the Agreement have pointed out that the labor chapter does not go far enough in a number of fronts. Perhaps the most important criticism is that enforcement action continues to rely on a state-to-state dispute settlement mechanism that is essentially the same as in NAFTA and has proven not to be effective when one of the parties is unwilling to solve the dispute. If the parties wanted to ratchet up enforcement of potential labor violations or any other commitments in the Agreement, this would be an important area to focus on.

Now that the Agreement has been signed and the ratification process commences with a new Congress in the United States, a number of Democratic legislators have urged for changes that can ensure enforcement on labor rights. This will be an important and probably contentious process, given that the Agreement already reflects a compromise between the parties. We will have to see the content of the domestic labor reform to be implemented in Mexico and its own enforcement mechanisms. This legislation is, in any case, a condition for the entry into force of the Agreement. 
However imperfect, the USMCA has signaled a new direction in thinking about labor concerns in trade agreements, going well beyond the labor chapter. It has also made use of bargaining power during negotiations to push for domestic labor reforms, although these reforms focused only on Mexico. These are welcome developments, and it may be reasonable to expect changes in these and other areas of future trade agreements if labor concerns remain in the foreground. 